\title{
Total phenolic contents, antioxidant and antibacterial activities of chia seeds (Salvia hispanica L.) having different coat color
}

\author{
Yunus Emre TUNÇiL'1, Ömer Faruk ÇELIK' ${ }^{1}$ \\ 1Food Engineering Department, Agricultural Faculty, Ordu University, Ordu
}

Alınış tarihi: 16 Şubat 2019, Kabul tarihi: 29 Mart 2019

Sorumlu yazar: Yunus Emre TUNÇiL, e-posta: yunustuncil@odu.edu.tr

\begin{abstract}
Due to its high nutritional value and healthpromoting effects, there is an increasing interest in utilizing chia seed in the human diet. The aim of this study was to compare the compositional and functional characteristics of white and black chia seeds that are commercially available in Turkey. Compositional comparisons were done by quantifying protein, oil, ash and moisture contents. The total phenolic content and antioxidant activity were measured using defatted ground chia seeds. Our results revealed that black chia seeds had significantly higher protein, ash and moisture contents, compared to white chia seeds, but no difference was found in terms of oil content $(\mathrm{P}>$ 0.05). Conversely, the total phenolic content of white chia seeds $(3.52 \pm 0.08 \mathrm{mg}$ GAE [gallic acid equivalent]/g sample) was significantly higher than those in black seeds (3.42 $\pm 0.06 \mathrm{mg} \mathrm{GAE} / \mathrm{g}$ sample) $(\mathrm{P}<0.05)$. Consequently, a significant difference $(\mathrm{P}<$ 0.05) was observed between DPPH free radical scavenging activities of white and black chia seeds, with the former exhibiting $231.5 \pm 6.3 \mu \mathrm{mol}$ Trolox equivalent $(\mathrm{TE}) / \mathrm{g}$, and the latter having $197.5 \pm 7.4$ $\mu \mathrm{mol} \mathrm{TE} / \mathrm{g}$. The higher antioxidant activity of white chia seed was further confirmed by calculating $\mathrm{IC}_{50}$ values $\left(\mathrm{IC}_{50}\right.$ of black chia seed $=2.001 \mathrm{mg} / \mathrm{ml}$ vs that of white chia seed $=1.735 \mathrm{mg} / \mathrm{ml}$ ). Finally, we assessed antibacterial activities of chia seed extract and chia seed oil against human pathogens using agar disc-diffusion and agar well-diffusion assays. However, neither of the assays had shown antimicrobial activity against the tested bacteria. Considering the previously published reports, chia seed and chia seed oil seem to possess species-, and even strain-, specific antimicrobial activities. Overall,
\end{abstract}

the results of this study suggest that white chia seed has better functional properties than black seeds.

Key words: White chia seed, black chia seed, DPPH

Farklı kabuk renklerine sahip çiya tohumlarının (Salvia hispanica L.) toplam fenolik içerikleri, antioksidan ve antibakteriyel aktiviteleri

\section{Öz}

Yüksek besin değeri ve sağlığı destekleyici etkileri nedeniyle çiya tohumunun, beslenme amaçlı kullanımına olan ilgi artmaktadır. Bu çalışmanın amacl, Türkiye'de ticari olarak temin edilebilen beyaz ve siyah olmak üzere farklı tohum kabuğu rengine sahip çiya tohumlarının bileşimlerini ve fonksiyonel özelliklerini karşılaştırmaktır. Çiya tohumlarının bileşimlerini karşılaştırmak amacıyla protein, yağ, kül ve nem içerikleri belirlenmiştir. Toplam fenolik içeriği ve antioksidan potansiyeli gibi fonksiyonel özelliklerin belirlenmesinde ögütülmüş ve yağı uzaklaştırılmış çiya tohumları kullanılmıştır. Yağ içerikleri arasında herhangi bir fark bulunamazken, beyaz çiya tohumlarının siyah çiya tohumlarına kıyasla anlamlı derecede daha yüksek protein, kül ve nem içerdiği ortaya koyulmuştur $(\mathrm{P}<0.05)$. Benzer şekilde, beyaz çiya tohumlarının toplam fenolik içeriği $(3.52 \pm 0.08 \mathrm{mg} \mathrm{GAE}$ [gallik asit eşdeğeri] / g numune), siyah muadillerinden (3.42 \pm $0.08 \mathrm{mg} \mathrm{GAE} / \mathrm{g}$ numune) önemli derecede daha yüksektir $(P<0.05)$. Buna bağlı olarak, beyaz ve siyah çiya tohumlarının DPPH serbest radikal süpürme aktiviteleri arasında da anlamlı bir fark $(\mathrm{P}<$ 0.05 ) olduğu belirlenmiş olup beyaz çiya $231.5 \pm 6.3$ $\mu$ mol Trolox eşdeğeri (TE) / g, siyah çiya ise $197.5 \pm$ $7.4 \mu \mathrm{mol}$ TE / g aktivite sergilemiştir. Ayrıca, IC $_{50}$ 
değerleri de hesaplanarak beyaz çiya tohumlarının daha yüksek olduğu belirlenen antioksidan aktivitesi bir kez daha teyit edilmiştir (siyah çiya tohumu için $\mathrm{IC}_{50}=2.001 \mathrm{mg} / \mathrm{ml}$, beyaz çiya tohumu için $\mathrm{IC}_{50}=$ $1.735 \mathrm{mg} / \mathrm{ml}$ ). Son olarak, çiya tohumu ekstraktları ve yağlarının daha önce çalışılmamış olan insan patojenlerine karşı antibakteriyel aktiviteleri agar disk difüzyon ve agar kuyucuk difüzyon yöntemleri kullanılarak belirlenmiştir. Ancak, test edilen hiçbir bakteriye karşı antibakteriyel etkiye rastlanmamış olup önceki yayınlar da göz önüne alındığında çiya tohumunun ve çiya tohumu yağının bakteri türüne, hatta suşa özgü antimikrobiyal etki sergilediği öne sürülebilir. Sonuç olarak, bu çalışmada elde edilen verilere bakıldığında siyaha kıyasla beyaz çiya tohumlarının daha iyi fonksiyonel özelliklere sahip olduğu söylenebilir.

Anahtar kelimeler: Beyaz çiya tohumu, siyah çiya tohumu, DPPH

\section{Introduction}

Chia (Salvia hispanica L.) is an annual herbaceous plant belonging to Lamiaceae family. It is originated from southern Mexico and northern Guatemala and can grow in the arid and semi-arid regions of the world due to its low water requirements (Ayerza, 1995; Coates and Ayerza, 1996; Coates and Ayerza, 1998). For commercial purposes, chia has been cultivated in Argentina, Australia, Bolivia, Colombia, Ecuador, Paraguay and Peru (Oliveira-Alves et al., 2017). Although different parts of the plant have been used for feeding, medicinal, and pharmaceutical purposes, the most attractive part of the plant is the seed (Ullah et al., 2016), which has been a part of human diet since 3500 BC (Munoz et al., 2013). Chia seed has been directly consumed as whole grain or grounded in refreshing drinks and salads. It has been also added as an ingredient in the production of many bakeries such as bread, cakes, and cookies (Valdivia-Lopez and Tecante, 2015). Chia seed is small (couple millimeters in length) with an oval, slightly flattened shape and may have a color ranging from white to black (Munoz et al., 2013). Although the composition of chia seed highly depends on the growing location, it approximately contains 5.8\% water, $16.5 \%$ protein, $30.7 \%$ oil, $4.8 \%$ ash, $34.4 \%$ dietary fiber (USDA, 2018). It is a good source of not only minerals including calcium, phosphorus, potassium, and magnesium but also vitamins such as ascorbic acid and niacin (USDA, 2018). Moreover, recent advances have revealed that chia seed is rich in phenolic and antioxidant substances (Marineli et al., 2014). In recent years, chia seed as part of the human diet has started to gain increasing attention and been considered as a "functional food" due to its high nutritional value and health-promoting effects. Consumption of chia seed has been shown to decrease cholesterolemia (Ayerza \& Coates, 2005), modulate glycemic and insulinemic responses (Chicco et al., 2009), improve intestinal function (Chañi et al., 2018), and play a protective role against cardiovascular diseases (Vuksan et al., 2008). These health-promoting effects are attributed to its constituents, mainly to its oil, dietary fibers, and antioxidant compounds (Munoz et al., 2013). The chia seed oil consisting of $11.1 \%$ of saturated fatty acids, $7.3 \%$ of mono-unsaturated fatty acids, and $81.6 \%$ of poly-unsaturated fatty acids, has been reported as a rich source of $\alpha$-linolenic acid ( $\omega-3$, an essential fatty acid) (Ayerza, 2010; Marineli et al., 2014 ), and the consumption of $\alpha$-linolenic acid has been associated with the prevention of cardiovascular diseases and inflammatory syndromes (Albert et al., 2005; Garg et al., 2006). Dietary fibers found in chia seed include soluble fibers and mucilage that could lower the cholesterol, decrease inflammatory responses and regulate bowel transit (Munoz et al., 2013). Another constituent of chia seed that has recently taken great attention is its phenolic compounds due to their numerous health-promoting effects. The main phenolic compounds found in chia seed are caffeic and rosmarinic acids (Capitani et al., 2012; MartinezCruz \& Paredes-Lopez, 2014; Oliveira-Alves et al., 2017; Reyes-Caudillo et al., 2008), which have been shown to play a significant role in the prevention of neurological disorders, inflammation, and diabetes (Coelho et al., 2015; Jayanthy and Subramanian, 2014; Petersen and Simmonds, 2003). Additionally, chlorogenic and protocatechuic acids (Capitani et al., 2012; Reyes-Caudillo et al., 2008), and flavonoids such as myricetin, quercetin and kaempferol have been identified in chia seeds (Capitani et al., 2012). Such phenolics have been shown to have antioxidative, anti-inflammatory, and anti-mutagenic properties; thus, they could protect against cardiovascular diseases and cancer formation (Panche et al., 2016). Previous studies have shown that chia seed composition, mainly total oil content, fatty acid profile, protein content and amino acid compositions are significantly affected by geographical location (Ayerza, 1995; Ayerza and 
Coates, 2004; Ayerza, 2010; Ayerza, 2013). For instance, chia grown in Peru was found to contain higher protein and oil contents compared to that grown in Argentina, Columbia, and Bolivia (Ayerza and Coates, 2004). Differences in total phenolic contents of chia seeds harvested from different locations were also observed. For example, the total phenolic content of Chilean chia seed has been reported to be $0.94 \mathrm{mg}$ gallic acid equivalent (GAE)/g of sample (Marineli et al., 2014), whereas that of Mexican chia seed has been found to be $1.64 \pm$ $0.21 \mathrm{mg} \mathrm{GAE} / \mathrm{g}$ of sample (Martinez-Cruz \& ParedesLopez, 2014). Typical seed coat color of chia changes from black and black spotted to white. The majority of commercialized chia seeds are presently blackspotted, but the popularity of white chia seeds in the market is increasing (Ayerza, 2013). Although the popularity of white chia seed is increasing, studies focusing on the compositional differences between commercially available white and black chia seeds are limited. Ayerza $(2010 ; 2013)$ have demonstrated no significant differences between chia seeds having white and black coat color in terms of oil, protein, dietary fiber, and amino acids contents. In addition, two chia genotypes which differ in seed color (white and black) have been shown to contain similar amounts of myricetin, quercetin, kaempferol, chlorogenic and caffeic acids (Ayerza, 2013). However, to the best of our knowledge, there is no study to compare the total phenolic contents and antioxidant activities of white and black chia seeds. Moreover, it has not been clearly known whether chia seeds show any antibacterial activity against human pathogens. Thus, the aim of this study was to compare the total phenolic contents, antioxidant activities as well as anti-microbial effects of white and black chia seeds that are commercially available in Turkey.

\section{Materials and Methods}

\section{Seeds}

Commercial white and black chia seeds (Figure 1) imported from Argentina and packed in polypropylene bags were purchased from a super market (Ordu, Turkey). Chia seeds were ground using a coffee grinder (SCM 2934, Sinbo, Istanbul, Turkey) to obtain powders that were further used for the following analysis as indicated below.

\section{Proximate analysis}

The moisture content was determined by drying the chia powder to a constant weight in a convection oven (Ecocell/EC 111, Germany) at $105 \pm 2{ }^{\circ} \mathrm{C}$ overnight. The nitrogen contents of the seeds were determined according to the Kjeldahl Method using an automatic distillation unit (UDK-149; VELP Scientifica, Italy). The protein concentrations were calculated multiplying the nitrogen content with the conversion factor of 6.25. Ash contents were determined by weight difference after combustion of chia powders at $550{ }^{\circ} \mathrm{C}$ in a furnace (Protherm furnaces, Ankara, Turkey) for 14 hours (at the end, grey-white residue color was obtained). The total fat content was determined by extracting the crude oil with hexane from dried chia powders using a solvent extractor system (SER 148; Velp Scientifica, Usmate, Italy) at $130^{\circ} \mathrm{C}$ for 150 minutes. Crude oil and defatted samples were kept for further analysis.
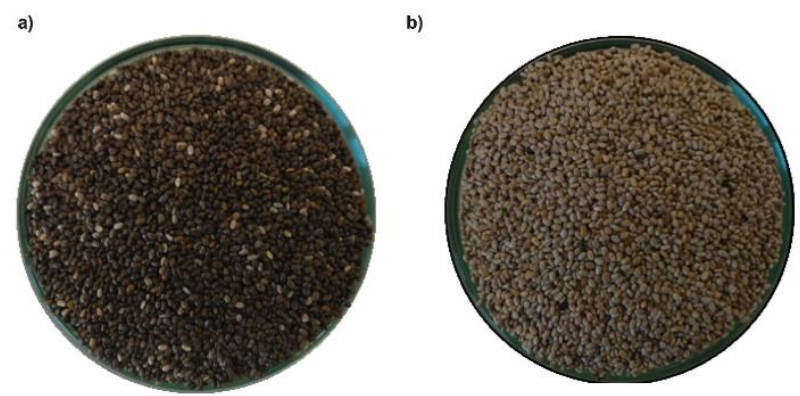

Figure 1. a) Black and b) white chia seeds used in the study

\section{Preparation of extracts}

In order to determine the total phenolic contents, antioxidant activities and antimicrobial capacities of samples, the extracts of defatted white and black chia seeds were prepared according to the method described by Oliveira-Alves et al. (2017) with some modifications. Briefly, 1 gram of defatted powder was extracted with $10 \mathrm{~mL}$ of $80 \%$ methanol $(\mathrm{v} / \mathrm{v})$ using a homogenizer (T18; IKA-Werke GmbH \& Co., Staufen, Germany) in an ice water bath at 15,000 rpm for 10 minutes followed by mixing at 2,000 rpm on a stirrer (UC152D; Stuart, Cole-Parmer Instrument Co., Chicago, IL) at room temperature for 2 hours. The mixture was then centrifuged at 4000 rpm (D-37520; Sigma Laborzentrifugen, Harz, Germany) for $20 \mathrm{~min}$ and the supernatant was used for the following analyses.

\section{Determination of the total phenolic contents}

The total phenolic content of chia extracts was determined using Folin-Ciocalteu reagent as previously described by Demirkol and Tarakci (2018). Briefly, $20 \mu \mathrm{l}$ of the extract was diluted with $1580 \mu \mathrm{l}$ of distilled water, followed by addition of $100 \mu \mathrm{l}$ of Folin-Ciocalteu reagent (2N) (Merck, 
Darmstadt, Germany) and $300 \mu \mathrm{l}$ of $\mathrm{Na}_{2} \mathrm{CO}_{3}$ (SigmaAldrich Corp., St. Louis, MO, USA) solution (7.5\%). The mixture was incubated for 2 hours at room temperature in the dark followed by measuring the absorbance at $760 \mathrm{~nm}$ using a spectrophotometer (UVmini-1240, Shimadzu, Japan). Gallic acid (SigmaAldrich Corp.) was used to construct the standard curve and the results were expressed as mg gallic acid equivalents (GAE) per gram of defatted sample.

\section{Determination of antioxidant activity}

Antioxidant activity was determined with 1,1diphenyl-2-picrylhydrazyl (DPPH) (Sigma Chemical Co.) assay, as previously described by Demirkol and Tarakci (2018). Briefly, various concentrations $(0.5$, $0.4,0.3,0.2$, and $0.1 \mathrm{mg} / \mathrm{ml}$ ) of the extracts were prepared with $80 \%$ methanol. One $\mathrm{ml}$ of DPPH solution $(2.49 \mathrm{mg}$ DDPH $/ 100 \mathrm{ml}$ of $80 \%$ methanol, which yielded an absorbance value of $\sim 0.9$ at 515 $\mathrm{nm}$ ) were added on $50 \mu \mathrm{l}$ of diluted extracts, followed by incubation for 30-minute at room temperature in the dark. Afterwards, the absorbance readings were recorded at $515 \mathrm{~nm}$ wavelength using a spectrophotometer (UVmini-1240, Shimadzu, Japan). Trolox (Sigma-Aldrich Corp.) was used to construct the standard curve and the results were expressed as $\mu \mathrm{mol}$ Trolox equivalent (TE) per gram of defatted sample. The inhibition (\%) values were calculated using the following equation where $A_{0}$ is the absorbance of the control and $A_{1}$ is the absorbance of the samples tested;

$\%$ Inhibition $=\left[\left(\mathrm{A}_{0}-\mathrm{A}_{1}\right) / \mathrm{A}_{0}\right] \times 100$

A standard curve was plotted using the inhibition (\%) values against different concentrations of chia extracts. The amount of extract $(\mathrm{mg} / \mathrm{mL})$ required for the inhibition of $50 \%$ of the DPPH $\left(\mathrm{IC}_{50}\right)$ was calculated.

\section{Antibacterial activity}

Staphylococcus aureus NCTC 8530, Escherichia coli BL21, Bacillus subtilis NRRL-B209, and Listeria monocytogenes ATCC 7644 were used as model bacteria to determine the antibacterial activity of crude oils and methanol extracts of chia seed powders. All bacteria were cultivated in Tryptic Soy Broth (TSB; Merck, Darmstadt, Germany) at $37^{\circ} \mathrm{C}$ and passaged in the same medium overnight prior to the assay. The concentrations of selected bacteria were adjusted to an optical density of $0.09 \pm 0.005$ at $600 \mathrm{~nm}$ wavelength (corresponding to McFarland=0.5). A $100 \mu \mathrm{L}$ of bacterial culture was spread-plated onto Mueller-Hinton Agar (MHA;
Merck, Darmstadt, Germany) with sterile cotton swabs. The MHA volume transferred to sterile petri dishes ( $90 \mathrm{~mm}$ diameter) was fixed to $20 \mathrm{~mL}$ to obtain reliable results. When cultures were absorbed to the media completely, antibacterial activity assays were performed. Following incubation, inhibition zone diameters were measured using a digital caliper. Three replicates were conducted against each bacteria for each extract.

Agar Disc-diffusion assay: Sterile filter paper discs (Bioanalyse LLC, Ankara, Turkey) with a diameter of $6 \mathrm{~mm}$ were placed on the MHA and followed by impregnation of either extracts or crude oils $(10 \mu \mathrm{L})$ to the discs with a micropipette. All plates were incubated at $37^{\circ} \mathrm{C}$ for 24 hours (Alzoreky and Nakahara, 2003).

Agar well-diffusion assay: In each petri dish, four holes (with a diameter of $6 \mathrm{~mm}$ ) were punched aseptically with a sterile cork borer and $50 \mu \mathrm{L}$ of the extracts and crude oils were introduced into the wells. Then, the dishes were incubated at $37^{\circ} \mathrm{C}$ for 24 hours (Stepanović et al., 2003).

\section{Statistical analysis}

All analyses were performed in triplicate and the results were expressed as means \pm standard errors. Statistical analyses were performed using GraphPad Prism version 7.0 for Mac OS X (GraphPad Software, Inc. La Jolla, CA). One-tailed unpaired student's t-test $(\mathrm{P}<0.05)$ was performed at $\alpha=0.05$ significant level to determine the differences between white and black chia seeds.

\section{Results and Discussion}

\section{Proximate analysis}

The moisture, protein, oil, and ash contents of white and chia seeds are given in Figure 2. Black chia seeds were found to have significantly higher moisture content (6.19\%) than white chia seeds (5.71\%) $(\mathrm{P}<$ 0.05) (Figure 2a). Similarly, black chia seeds exhibited significantly $(\mathrm{P}<0.05)$ higher protein $(21.7 \%)$ and ash (4.67 \%) contents, compared to its white counterparts that contained $17.3 \%$ protein and $4.5 \%$ ash (Figure 2b, d). However, no significant difference was found between the oil contents of black and white chia seeds $(34.2 \%$ and $32.9 \%$, respectively) (Figure 2c). Overall, these findings agree with the literature, as the results obtained in this study fall into the ranges reported by others (Bushway et al., 1981; Ayerza, 2013; Marineli et al., 2014). On the other hand, except the oil content, our current results disagreed with the findings of Ayerza 
(2013) who reported no significant differences in terms of water and protein contents between chia genotypes known as Tzotzol and Iztac, which has black-spotted and white seed, respectively. The discrepancies in the results could be attributed to differences in plant growing locations. Ayerza (Ayerza, 2010, 2013) demonstrated that the

a)

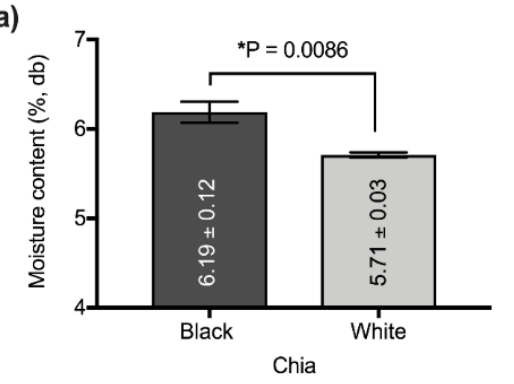

c)

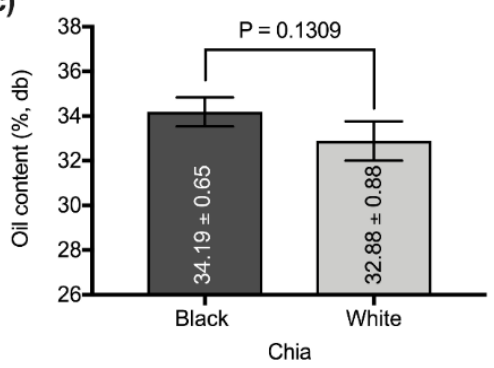

compositions of chia seeds are highly dependent on the harvesting location. Although the seeds used in this study were harvested in Argentina, the exact location is unfortunately unknown; thus, they could have been cultivated from very different locations in Argentina, which could possibly cause significant differences in proximate analysis.

b)

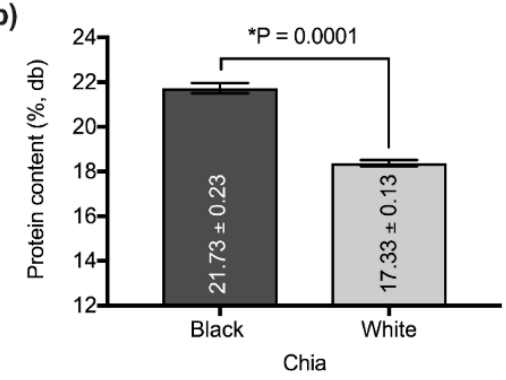

d)

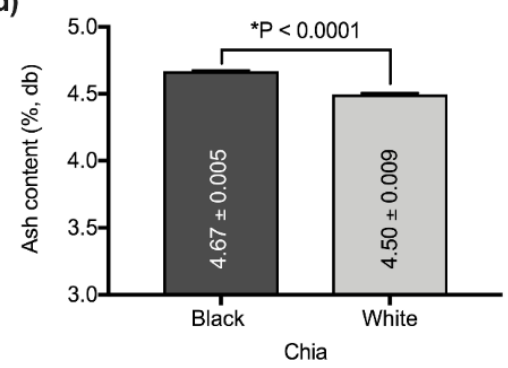

Figure 2. a) Moisture, b) protein, c) oil, d) ash contents (\%) of black and white chia seeds used in the study. Error bars represent the standard errors of the means of three separate replicates. Samples having significant difference (one-tailed, unpaired student's t-test, $\mathrm{P}<0.05$ ) are indicated with an asterisk. db: dry basis.

\section{Total phenolic contents}

Total phenolic contents of the defatted ground chia seeds are given in Figure 3. The total phenolic contents of white and black chia seeds were found to be $3.52 \pm 0.08$ and $3.42 \pm 0.06 \mathrm{mg} \mathrm{GAE} / \mathrm{g}$ defatted chia seeds, respectively. These results are overall $\sim 3.7$ times higher than Chilean chia seeds (Marineli et al., 2014) and 2.2 times higher than Mexican chia seeds (Martinez-Cruz \& Paredes-Lopez, 2014). They reported the total phenolic content of Chilean chia seeds to be $0.94 \pm 0.06 \mathrm{mg} \mathrm{GAE} / \mathrm{g}$ sample, and Mexican chia seeds to be $1.64 \pm 0.08 \mathrm{mg}$ GAE $/ \mathrm{g}$ sample, respectively. It should be noted here that none of these reports mentioned whether the tested seeds have black or white coat color. The differences in total phenolic content between our study and the others could be due to two factors; i) the samples used in our study and in the others are harvested from different locations, and it has been proven that growing locations significantly impact the composition of chia seeds (Ayerza, 1995; Ayerza and Coates, 2004; Ayerza, 2010; Ayerza, 2013); ii) the methods used for the extraction of phenolic compounds in different studies vary, and different extraction methods have been shown to dramatically influence the total phenolic contents of chia seeds measured (Scapin et al., 2016). Comparatively, the total phenolic content of white chia seed was significantly higher than its black counterpart $(\mathrm{P}<$ 0.05 , one-tailed student's t-test) (Figure 3 ). This result disagrees with the findings of Ayerza (2013) who, in terms of the amounts of some phenolics (myricetin, quercetin, kaempferol, cholorgenic and caffeic acids), reported insignificant differences between chia seeds belonging to Tzotzol and Iztac genotypes that are black and white in color, respectively. 


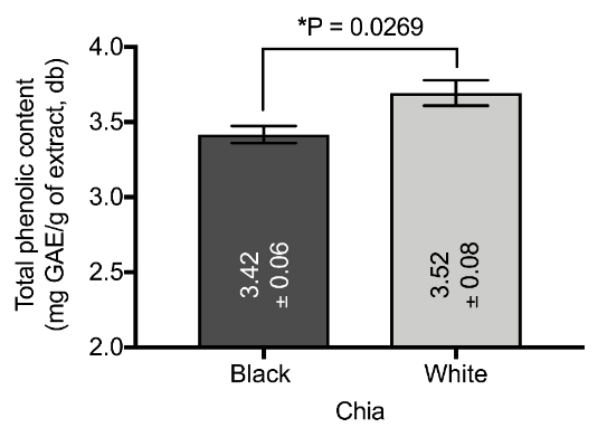

Figure 3. Total phenolic contents [mg gallic acid equivalent (GAE)/g of sample) of black and white chia seed extracts. Error bars represent the standard errors of the means of three separate replicates. Samples having significant difference (one-tailed, unpaired student's t-test, $\mathrm{P}<0.05$ ) are indicated with an asterisk. db: dry basis.

Unfortunately, Ayerza (2013) did not measure the total phenolic contents of chia seeds in the study; thus, the differences that found in the current study could be due to the variances in the amount of other phenolics that are generally present in the chia seeds, but not measured by Ayerza (2013), such as rosmarinic acid and protocatechuic ethyl ester, which are the main phenolics found in chia seed (Martinez-Cruz \& Paredes-Lopez, 2014).

\section{Antioxidant activity}

Total antioxidant activities of white and black chia seeds were determined by testing the DPPH free radical scavenging activity of the defatted extracts (Figure $4 \mathrm{a}$ ) as well as calculating the $\mathrm{IC}_{50}$ values (Figure 4b). DPPH radical scavenging activities of white chia seed were found to be significantly higher

a)

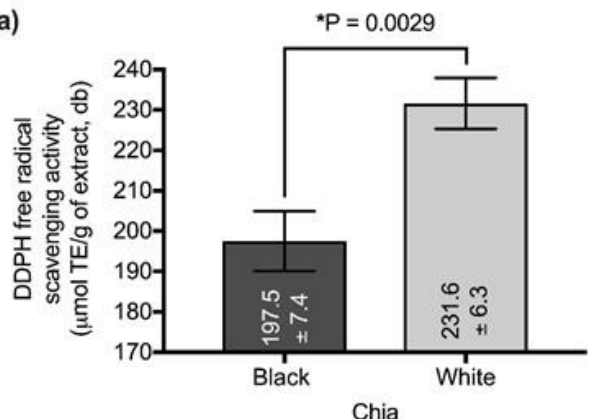

[231.6 $\pm 6.3 \mu \mathrm{mol}$ Trolox equivalent (TE)/g of extract] than its black counterpart $(197.5 \pm 7.4 \mu \mathrm{mol} \mathrm{TE} / \mathrm{g}$ of extract) $(\mathrm{P}<0.05)$. The higher antioxidant activity of white chia seed was also further confirmed by calculating the $\mathrm{IC}_{50}$ values, which is defined as the concentration of the sample required to inhibit 50\% of DPPH radical. The $\mathrm{IC}_{50}$ value of black chia seed extract was found to be $2.001 \mathrm{mg} / \mathrm{ml}$, while that of white chia seed extract was calculated as 1.735 $\mathrm{mg} / \mathrm{ml}$. The higher antioxidant activity of white chia seed could be attributed to the higher total phenolic contents that it has (Figure 3). Overall, these findings match with those reported by Capitani et al. (2012) who demonstrated defatted chia seed has total antioxidant activity of $226.6 \pm 4.13 \mu \mathrm{mol} \mathrm{TE} / \mathrm{g}$ of meal. On the other hand, our results are lower than those reported for defatted Chilean seed flour (436.6 $\pm 9.7 \mu \mathrm{mol} \mathrm{TE} / \mathrm{g}$ of exctract) (Marineli et al., 2014), Argentinian chia fibrous fraction (446.4 \pm 19.8 $\mu \mathrm{mol} \mathrm{TE} / \mathrm{g}$ of sample) (Capitani et al., 2012), and Mexican chia fibrous fraction $(488 \mu \mathrm{mol} \mathrm{TE} / \mathrm{g}$ of sample) (Vazquez-Ovando et al., 2009). Besides location effects, the differences between the findings could be attributed to the various techniques used for the extraction process, which have been shown to noticeably influence the final results of antioxidant activity of chia seeds (Scapin et al., 2016). Our results also show that, regardless of seed color, chia seed has higher antioxidant activity than other highly edible cereals such as sorghum, millet, barley, rye, and wheat, which have $195.8 \pm 8.82,23.83 \pm 0.67$, $21.00 \pm 0.83,12.17 \pm 0.50$, and $4.33 \pm 0.17 \mu \mathrm{mol}$ $\mathrm{TE} / \mathrm{g}$ of sample, respectively (Ragaee et al., 2006).

b)

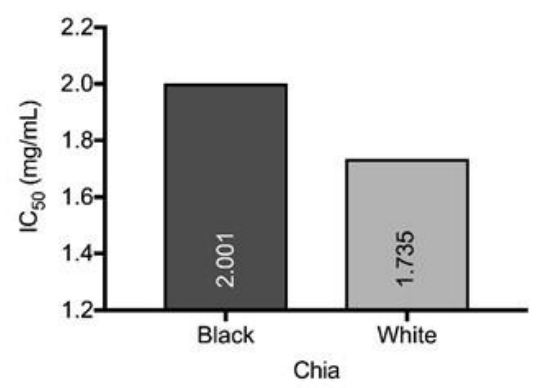

Figure 4. Total antioxidant activities of black and white chia seeds as determined a) by measuring the DPPH free radical scavenging activities [ $\mu$ mol Trolox equivalent (TE)/g of extract] and b) by calculating the $\mathrm{IC}_{50}$ values of the extracts. The $\mathrm{IC}_{50}$ value is defined as the concentration of the sample required to inhibit $50 \%$ of DPPH radicals. Error bars represent the standard errors of the means of three separate replicates. Samples having significant difference (one-tailed, unpaired student's t-test, $\mathrm{P}<0.05$ ) are indicated with an asterisk. db: dry basis. 


\section{Antibacterial effect}

Chia seed has been previously shown to have antimicrobial activities against periodontal pathogens, including Porphyromonas gingivalis, Fusobacterium nucleatum, and Aggregatibacter actinomycetemcomitans (Divyapriya et al., 2016). Like chia seed, its essential oil has been more recently demonstrated to exhibit antimicrobial effect against some phytopathogenic fungi (Monilinia laxa, M. fructicola, M. fructigena, Aspergillus flavus, $A$. niger, A. fumigatus, Penicillium digitatum, $P$. expansum, Sclerotinia sclerotiorum, and Fusarium oxysporum) and bacteria (Bacillus megaterium, $B$. megaterium, B. mojavensis, Clavibacter michiganensis, Xanthomonas campestris, $X$. vesicatoria, Pseudomonas syringae, Escherichia coli Migula, P. savastanoi, Burkholderia gladioli) (Elshafie et al., 2018). Here, the antibacterial activities of chia seed extract and chia seed oil against previously untested human pathogens Staphylococcus aureus NCTC 8530, Bacillus subtilis NRRL-B209, and Listeria monocytogenes ATCC 7644 as well as an untested strain of Escherichia coli BL21 were assessed using agar disc-diffusion and agar well-diffusion assays. No antimicrobial activity against any of the bacteria tested in either assays was observed (Figure 5), suggesting that, considering the previously published reports (Divyapriya et al., 2016; Elshafie et al., 2018), chia seed and seed oil show species-, and even strain-, specific antimicrobial activities.
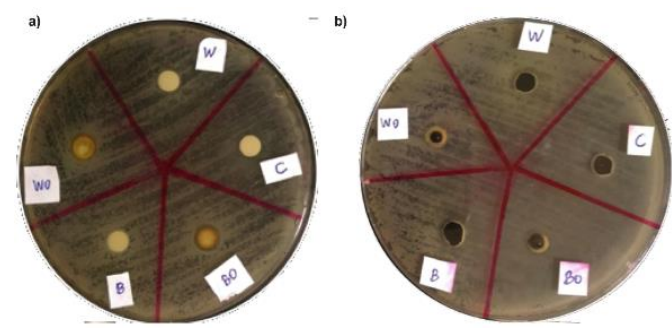

Figure 5. Antibacterial activity of chia seed extracts and oils against $B$. subtilis using $(\mathrm{A})$ agar disc-diffusion and (B) agar well-diffusion assays: C: control, W: White chia seed extact, WO: white chia seed oil, B: black chia seed extract, BO: black chia seed oil. No antibacterial activity of $\mathrm{W}, \mathrm{WO}, \mathrm{B}$, and BO was observed against $S$. aureus, $L$. monocytogenes, E. coli in any of the assays

\section{Conclusion}

The results of this study demonstrate that chia seed coat color showed significant impact on the moisture, protein, and ash contents, but not the oil content. Furthermore, white chia seed was found to contain significantly higher amount of total phenolic compounds, compared to its black counterparts, and accordingly white chia seed exhibited higher antioxidant activity. It is worth to mention that, in this study, black and white chia seeds harvested in Argentina and commercially available in Turkey were used. Unfortunately, it is unknown whether white and black chia seeds were grown in the same location in Argentina. Therefore, in order to eliminate the location effect on the composition and functional properties, further research on white and black chia seeds growing in the same location is required that would confirm the findings of this study.

\section{References}

Albert, C. M., Oh, K., Whang, W., Manson, J. E., Chae, C. U., Stampfer, M. J., Willett, W. C., Hu, F. B. 2005. Dietary alpha-linolenic acid intake and risk of sudden cardiac death and coronary heart disease. Circulation, 112: 3232e3238.

Alzoreky, N. S., Nakahara K. 2003. Antibacterial activity of extracts from some edible plants commonly consumed in Asia. International journal of food microbiology, 80(3): 223-230.

Ayerza, R. 1995. Oil content and fatty acid composition of chia (Salvia hispanica L.) from five northwestern locations in Argentina. Journal of American Oil Chemists' Society, 72:1079-1081.

Ayerza, R., Coates, W. 2004. Composition of chia grown in six tropical and sub-tropical ecosystems of South America. Tropical Science, 44:131-135.

Ayerza, R., Coates, W. 2005. Ground chia seed and chia oil effects on plasma lipids and fatty acids in the rat. Nutrition Research, 25(11): 995-1003.

Ayerza, R. 2010. Effects of Seed Color and Growing Locations on Fatty acid content and composition of two chia genotypes. Journal of the American Oil Chemists Society, 87(10): 1161-1165.

Ayerza, R. 2013. Seed composition of two chia genotypes which differ in seed color. Emirates Journal of Food and Agriculture, 25(7): 495-500.

Bushway, A. A., Belyea, P. R., Bushway, R. J. 1981. Chia seed as a source of oil, polysaccharide, and protein. Journal of Food Science, 46(5): 1349-\&.

Capitani, M. I., Spotorno, V., Nolasco, S.M., Tomas, M.C. 2012. Physicochemical and functional characterization of by-products from chia seeds of Argentina. Lwt, 45(1): 94-102.

Chicco, A. G., D'Alessandro, M. E., Hein, G. J., Oliva, M. E., Lombardo, Y. B. 2009. Dietary chia seed (Salvia hispanica L.) rich in alpha-linolenic acid improves adiposity. British J of Nutrition, 101(1): 41-50. 
Coates, W., Ayerza, R. 1996 Production potential of chia in Northwestern Argentina. Industrial Crops and Production, 5: 229-233.

Coates, W., Ayerza, R. 1998 Commercial production of chia in Northwestern Argentina. Journal of the American Oil Chemists' Society, 75: 1417-1420.

Coelho, V. R., Vieira, C. G., Souza, L. P., Moysés, F., Basso, C., Papke, D. K. M., Pereira, P. 2015. Antiepileptogenic, antioxidant and genotoxic evaluation of rosmarinic acid and its metabolite caffeic acid in mice. Life Sciences, 122: 65-71.

Demirkol, M., Tarakci, Z. 2018. Effect of grape (Vitis labrusca L.) pomace dried by different methods on physicochemical, microbiological and bioactive properties of yogurt. LWT-Food Science and Technology, 97: 770-777.

Divyapriya, G. K., Veeresh, D. J., Yavagal, P. C. 2016. Evaluation of antibacterial efficacy of chia (Salvia hispanica) seeds extract. An in-vitro study. International Journal of Ayurveda Pharmaceutical Research, 4:22-24.

Elshafie, H. S., Aliberti, L., Amato, M., De Feo, V., Camele, I. 2018. Chemical composition and antimicrobial activity of chia essential oil. European Food Research and Technology, 244(9): 1675-1682.

Evelyn, M., Montes-Chañi, E. M. M., Pacheco, S. O. S., 2018. Long-Term Dietary Intake of Chia Seed Is Associated with Increased Bone Mineral Content and Improved Hepatic and Intestinal Morphology in Sprague-Dawley Rats. Nutrients, 10: 922.

Garg, M. L., Wood, L. G., Singh. H., Moughan, P. J. 2006. Means of delivering recommended levels of long chain n-3 polyunsaturated fatty acids in human diets. Journal of Food Science, 71: 66-71.

Jayanthy, G., Subramanian, S.. 2014. Rosmarinic acid, a polyphenol, ameliorates hyperglycemia by regulating the key enzymes of carbohydrate metabolism in high fat diet. Biomedicine and Preventive Nutrition, 4(3): 431-437.

Marineli, R. D,. Moraes, E. A., Lenquiste, S. A., Godoy, A.T., Eberlin, M. N., Marostica, M. R. 2014. Chemical characterization and antioxidant potential of Chilean chia seeds and oil (S. hispanica L.). LwtFood Science and Technology, 59(2): 1304-1310.

Martinez-Cruz, O., Paredes-Lopez, O. 2014. Phytochemical profile and nutraceutical potential of chia seeds by ultra high performance liquid chromatography. J Chromatography, 13: 43-48.

Montes Chañi, E., Pacheco, S., Martínez, G., Freitas, M. R., Ivona, J. G., Ivona, J. A., Craig, W., Pacheco, F. 2018. Long-term dietary intake of chia seed is associated with increased bone mineral content. Nutrients, 10(7), 922.

Munoz, L. A., Cobos, A., Diaz, O., Aguilera, J. M. 2013. Chia Seed (Salvia hispanica): An Ancient Grain and a New Functional Food. Food Reviews International, 29(4): 394-408.

Oliveira-Alves, S. C., Vendramini-Costa, D. B., Cazarin, C. B. B., Marostica, M.R., Ferreira, J.P.B. Characterization of phenolic compounds in chia seeds, fiber flour. Food Chem, 232: 295-305.

Panche, A. N., Diwan, A. D., Chandra, S.R. 2016. Flavonoids: an overview. Journal of Nutritional Science, 5.

Petersen, M., Simmonds, M. S. J. 2003. Rosmarinic acid. Phytochemistry, 62:121-5.

Ragaee, S., Abdel-Aal, E. M., Noaman, M. 2006. Antioxidant activity and nutrient composition of selected cereals for food use. Food Chemistry, 98: 32-38.

Reyes-Caudillo, E., Tecante, A., Valdivia-Lopez, M. A.. 2008. Dietary fibre content and antioxidant activity of phenolic compounds present in Mexican chia seeds. Food Chemistry, 107(2): 656-663.

Scapin, G., Schmidt, M. M., Prestes, R. C., Rosa, C. S. 2016. Phenolics compounds, flavonoids and antioxidant activity of chia seed extracts obtained by different extraction conditions. International Food Research Journal, 23(6): 2341-2346.

Stepanović, S., Antić, N., Dakić, I., Švabić-Vlahović, M. 2003. In vitro antimicrobial activity of propolis and synergism between propolis and antimicrobial drugs. Microbiological Res, 158(4): 353-357.

Ullah, R., Nadeem, M., Khalique, A., Imran, M., Mehmood, S., Javid, A., Hussain, J. 2016. Nutritional and therapeutic perspectives of Chia. Journal of Food Science Technology-Mysore, 53(4): 1750-1758.

USDA. 2018. USDA National Nutrient Database for Standard Reference Full Report, Seeds, chia seeds.

Valdivia-López, M. A., Tecante, A. 2015. Chia (Salvia hispanica): A review of native mexican seed and its nutritional and functional properties. Advances in Food and Nutrition Res, 75:53-75.

Vazquez-Ovando, A., Rosado-Rubio, G., Chel-Guerrero, L., Betancur-Ancona, D. 2009. Physicochemical properties of a fibrous fraction from chia. Lwt-Food Science and Technology, 42(1): 168-173.

Vuksan, V., Jenkins, A. L., Jenkins, D. J. A., Rogovik, A. L., Sievenpiper, J. L., Jovanovski, E. 2008. Using cereal to increase dietary fiber intake to the recommended level and the effect of fiber on bowel function in healthy persons consuming North American diets. American J Clinical Nutrition, 88(5): 1256-1262. 